\title{
Nasal carriage of resistant Staphylococcus aureus in a medical student community
}

\author{
CAROLINA Y. GUSHIKEN ${ }^{1}$, LILIANE B. MEDEIROS ${ }^{1}$, BRUNA P. CORREIA ${ }^{2}$, JOYCE M. SOUZA ${ }^{1,3}$, \\ DANIELA V. MORIS ${ }^{1,3}$, VALERIA C. PEREIRA ${ }^{1}$, ROGERIO GIUFFRIDA ${ }^{3}$ and MARCUS V.P. RODRIGUES ${ }^{1,3}$ \\ ${ }^{1}$ Faculdade de Biomedicina, Universidade do Oeste Paulista/UNOESTE, Rua José \\ Bongiovani, 700, 19050-920 Presidente Prudente, SP, Brasil \\ ${ }^{2}$ Faculdade de Medicina de Presidente Prudente/FAMEPP, Universidade do Oeste Paulista/ \\ UNOESTE, Rua José Bongiovani, 700, 19050-920 Presidente Prudente, SP, Brasil \\ ${ }^{3}$ Programa de Pós-Gradução em Meio Ambiente e Desenvolvimento Regional, Universidade do Oeste Paulista/ \\ UNOESTE, Rodovia Raposo Tavares, Km 572, Bairro Limoeiro, 19067-175 Presidente Prudente, SP, Brasil
}

Manuscript received on March 8, 2016; accepted for publication on April 29, 2016

\begin{abstract}
Staphylococcus aureus can cause a variety of infections due to its high transmissibility, high pathogenic potential and resistance to multiple drugs, factors that contribute to the relevance of infections in healthcare services. The aim of this study was to document phenotypic and genotypic resistance factors of Staphylococcus aureus strains, isolated from nasal mucosa of medical students. A nasal swab was collected from the nares (nostrils) of 222 medical students. After collection, the samples were submitted to isolation and identification procedures. From 204 valid samples, 20.6\% (42 samples) were positive for S. aureus. For the assessment of phenotypic resistance by disk-diffusion technique, from 42 samples, $95.2 \%$ showed resistance to erythromycin, $42.8 \%$ to clindamycin, $16.6 \%$ to cephoxitin and $9.5 \%$ to oxacillin. The $\mathrm{D}$ test showed that $26.2 \%$ of samples were resistant to macrolides, lincosamides and streptogramin B. A PCR assay allowed for the evaluation of a genotypic resistance profile, in which $16.6 \%$ of the samples were positive for the $m e c A$ gene, $35.7 \%$ positive for the erm $C$ gene or ermA gene and $28.5 \%$ were positive for both genes. These results demonstrate that medical students can enter the healthcare service previously colonized by multidrug resistant strains and become potential spreaders in the hospital environment.
\end{abstract}

Key words: multidrug resistance, colonization, MLSB resistance, MRSA.

\section{INTRODUCTION}

Staphylococcus aureus can cause a large variety of infections, most of which are acquired in the hospital environment. The high transmissibility, high pathogenic potential and possible resistance to multiple antibiotics may contribute to the relevance of staphylococcal infections in hospitals

Correspondence to: Marcus Vinicius Pimenta Rodrigues

E-mail: mv_rodrigues@hotmail.com and healthcare assistant services. The majority of the human population is colonized by $S$. aureus asymptomatically (Moreira et al. 2013, Ribeiro et al. 2014).

Data for hospital acquired infections are higher in university hospitals (Nogueira et al. 2009). Nasal and perineum mucosa are the main niches for this bacteria. Colonized and infected individuals are capable of transferring $S$. aureus by 
direct or indirect contact. This phenomenon, called cross infection, is more efficient in hospitals, which can lead to increased risk to patients, especially those undergoing invasive procedures, and an increased use of antibiotics (Muto et al. 2003, Colli et al. 2009, Silva et al. 2012). The importance of $S$. aureus as a pathogen is attributable to the combination of virulence mediated by toxins, its invasive characteristics and profile of antibiotic resistance (Le Loir et al. 2003).

The dissemination of isolates resistant to antibiotics, most used in clinic practice, is a limiting factor for staphylococcal infection treatment (Fitzgerald et al. 2001). An important event during staphylococci therapy was the appearance of Methicillin-Resistant Staphylococcus aureus (MRSA) as a predominant Gram-positive pathogen in nosocomial infections. According to estimates, more than $50 \%$ of staphylococcal infections are acquired in healthcare service establishments (Finch 2006, Moreira et al. 2013, Nikfar et al. 2015). MRSA strains are resistant to all beta-lactams (penicillin, cephalosporin, carbapenems and monobactams) due to the expression of low affinity receptors. Beta-lactams clamp to bacterial enzymes that are present in the cell wall, such as Penicillin-Binding Protein (PBP), stopping the normal function of the enzyme. MRSA is capable of synthesizing variants of PBP2, such as PBP2a, which maintains its physiological function, but with low affinity to beta-lactams (Ratti and Sousa 2009, McCulloch et al. 2015). The mecA gene, PBP2 encoder, with regulator genes, is located in a mobile genetic element, the staphylococcal chromosomic cassette mec (SSCmec) (Enrigth et al. 2002). A large variety of types of SCCmec are already described, differing from each other according to the number of genes present in their genetic architecture. Some of those types are carriers of determinant genes to multiple antibiotics other than beta-lactams, for instance macrolides, licosamins, streptogramins, aminoglycosides and tetracycline, therefore when a bacterial cell acquires SCCmec it expresses a multidrug resistance phenotype (McCulloch et al. 2015).

Clindamycin is an alternative drug to treat infections caused by $S$. aureus in case of penicillin intolerance or a methicillin resistant strain, because it stops production of toxins and virulence factors by inhibiting protein synthesis. However, the acquired resistance has limited the use of this drug to staphylococci therapy. There are two mechanisms that result in the resistance to clindamycin, the efflux of macrolides, controlled by the $m r s A$ gene; and modification of the binding site at the ribosome, controlled by the erm gene (Erythromycin Ribosomal Methylase). The ribosomal methylation confers cross-resistance to macrolides, lincosamins and streptogramin B, called the $\mathrm{MLS}_{\mathrm{B}}$ phenotype of Staphylococcus spp. The presence of genes ermA or erm $C$ results in this cross-resistance phenotype, leading to the modification of the biding site due to the methylation of the residue A2058, located on the V domain of 23s rRNA (Daurel et al. 2008, Amorim et al. 2009, Moosavian et al. 2014, Saderi et al. 2011, Abbas et al. 2015).

The high frequency of infections by methicillin resistant Staphylococcus aureus (MRSA) has shown continued growth in hospital institutions worldwide. Studies of geographic dissemination of multidrug resistant epidemic clones of $S$. aureus in Brazil showed that isolates tested presented the same phenotype resistant to methicillin, and most of them $(>70 \%)$ were resistant to at least nine antibiotics. For this reason, it is important to take informed actions in prevention, reduction and treatment of infections by MRSA to reduce this transmission of multidrug resistant strains (Vivoni et al. 2006, Ratti and Sousa 2009). Understanding the epidemiology of Staphylococcus aureus has important implications for control methods. Because of this, the objective of the present study is to document the dissemination of nasal mucosa isolates from medical students and to identify the phenotypic and genotypic resistance factors. 


\section{MATERIALS AND METHODS}

The study included students who started medical school in 2012 (first year) and excluded students admitted in different periods as well as those presenting any signs of infection on their upper airways and/or who used antibiotics up to one month before the date of collection. The research was approved by the Committee of Ethics in Research of the University of Western São Paulo - UNOESTE (Plataforma Brasil: 14790013.8.0000.5515). As a control of all reactions, S. aureus ATCC 25923 were used. S. aureus ATCC 33591, S. aureus ATCC 29213 and S. aureus ATCC 19095 were used as reference and quality control of susceptibility tests. All samples were identified and tested for susceptibility to erythromycin $(15 \mu \mathrm{g})$, clindamycin $(2 \mu \mathrm{g})$, oxacilin $(1 \mu \mathrm{g})$ and cephoxitin $(30 \mu \mathrm{g})$, and were genotyped.

Samples were collected in September 2012. Samples were collected from nasal mucosa of participants with a sterile swab, moistened with saline previously sterilized, with gentle circular movement three times. The collected material was placed into sterile dry tubes and immediately sent to the Laboratory of Microbiology. Samples were striated in Mannitol Salt Agar (selective medium for Staphylococcus), incubated at $37^{\circ} \mathrm{C}$ for 24 hours and submitted to identification procedures.

Gram stains were performed to evaluate the morphology and specific coloration as well as the purity of isolates. After that, colonies were submitted to catalase and coagulase tests.

Additional acidification tests of Maltose, Trehalose, mannitol and Polymyxin B were assayed for differentiation of other coagulase positive Staphylococcus species.

Susceptibility testing was performed on all isolates using the disk diffusion method, and interpretation of the test was done in agreement with the Laboratory Standards Institute protocol (CLSI 2012). The inoculum was prepared from cultures in Brain Hearth Infusion (BHI) broth incubated for 4-6 hours before adjusting turbidity to 0.5 on the McFarland scale. Once the inoculum density was adjusted, the bacteria were spread with a sterile swab on the surface of Mueller Hinton Agar and subsequently the disks impregnated with the antibiotics, oxacillin, cephoxitin, clindamycin and erythromycin were placed on the agar surface. The D test was performed to evaluate the profile of clindamycin induced resistance, using disks impregnated with erythromycin and clindamycin at a distance of $20 \mathrm{~mm}$ from one another and then incubated at $35^{\circ} \mathrm{C}$ for 24 hours. Subsequently, antibiotic activity was evaluated by measuring the inhibition halo formed and interpreted based on the CLSI (CLSI 2012).

Determination of the genotypic resistance profile consisted of amplification of genes mecA, erm $\mathrm{A}$ and erm $\mathrm{C}$ by Polymerase Chain Reaction (PCR) (Coutinho et al. 2010), and analysis by electrophoresis running in a $1.7 \%$ agarose gel in $1 \mathrm{x}$ TBE buffer (Tris 90mM, Boric acid 90mM, EDTA $2 \mathrm{mM} \mathrm{pH} \mathrm{8.0)} \mathrm{stained} \mathrm{with} \mathrm{ethidium} \mathrm{bromide} 0.5$ $\mu \mathrm{g} / \mathrm{ml}$. Gels were compared to a $100 \mathrm{bp}$ Ladder (Amersham Pharmacia Biosciences Inc.) and photographed under ultraviolet light.

Prevalence of $S$. aureus was estimated by point in a 95\% confident interval. Statistical Kappa were calculated to evaluate the concordance between PCR and disk-diffusion results (Vieira and Garret 2005). Frequency of resistance genes showed by strains were compared between individuals gender by Chi-square test with correction for continuity of Yates, or exact Fisher, depending on data frequency. All comparisons were performed on Bioestat 5.3 software, with $5 \%$ significance level $(\mathrm{p}<0.05)$ (Ayres et al. 2007).

\section{RESULTS}

The total of 222 samples were collected from nasal mucosa of medical students and 8.1\% (18 samples) 
excluded from those who were being treated with antibiotics. From 204 valid samples, 86 (42.2\%) were collected from male participants and 118 (57.8\%) from female. After identification, 42 samples $(20.6 \%$; IC95\% $=15.0 \%$ to $26.1 \%)$ were positive for Staphylococcus aureus (SA). Resistance to erythromycin was observed in 40 samples $(95.2 \%$ of SA) and 3 showed intermediate resistance; 18 samples ( $42.8 \%$ of SA) were resistant to clindamycin and 2 presented intermediate resistance; 7 samples $(16.6 \%)$ were resistant to cephoxitin and; 4 $(9.5 \%)$ were resistant to oxacillin, and 1 showed intermediate resistance (Table I). D test showed 11 samples (26.2\%) resistant to MLS $_{\mathrm{B}}$ (Figure 1).

Genotype analysis demonstrated 07 samples $(16.6 \%)$ resistant to cephoxitin, presenting expression of gene mecA, characterized MRSA strains. Resistance to macrolides was observed in 15 samples (35.7\%) expressing erm $A$ gene, 15 showed gene erm $C$ and $12(28.5 \%)$ both genes (Table II). In addition, 1 strain $(8.3 \%)$ was positive for all 3 genes tested (mecA, ermA and ermC), signifying a potential multidrug resistant strain (Fig. 2). Furthermore, 2 strains $(4.7 \%)$ showed non-expressed erm $A$, as presented by resistance to erythromycin.

TABLE I

Percentage frequency of resistance to antibiotics tested in samples from medical students.

\begin{tabular}{ccccc}
\hline Profile & Erythromycin $(\mathbf{n}=\mathbf{4 2})$ & Clindamycin $(\mathbf{n}=\mathbf{4 2})$ & Cephoxitin $(\mathbf{n}=\mathbf{4 2})$ & Oxacilin $(\mathbf{n}=\mathbf{4 2})$ \\
\hline Sensible & $4.76(\mathrm{n}=2)$ & $52.38(\mathrm{n}=22)$ & $83.33(\mathrm{n}=35)$ & $88.10(\mathrm{n}=37)$ \\
Resistant & $95.24(\mathrm{n}=40)$ & $47.62(\mathrm{n}=20)$ & $16.67(\mathrm{n}=7)$ & $11.90(\mathrm{n}=5)$ \\
$\mathbf{p}$ value & $<0.0001^{*}$ & & & \\
\hline
\end{tabular}

*Chi-square test.

TABLE II

Percentage frequency of positive and negative strains to genes mecA, erm $A$ and $\operatorname{erm} C$.

\begin{tabular}{cccc}
\hline Profile & $\boldsymbol{m e c} \boldsymbol{A}(\mathbf{n}=\mathbf{4 2})$ & $\boldsymbol{e r m} \boldsymbol{A}(\mathbf{n}=\mathbf{4 2})$ & $\boldsymbol{e r m} \boldsymbol{C}(\mathbf{n}=\mathbf{4 2})$ \\
\hline Positive & $16.67(\mathrm{n}=7)$ & $64.29(\mathrm{n}=27)$ & $64.29(\mathrm{n}=27)$ \\
Negative & $83.33(\mathrm{n}=35)$ & $35.71(\mathrm{n}=15)$ & $35.71(\mathrm{n}=15)$ \\
p value & $<0.0001^{*}$ & & \\
\hline
\end{tabular}

*chi-square test.

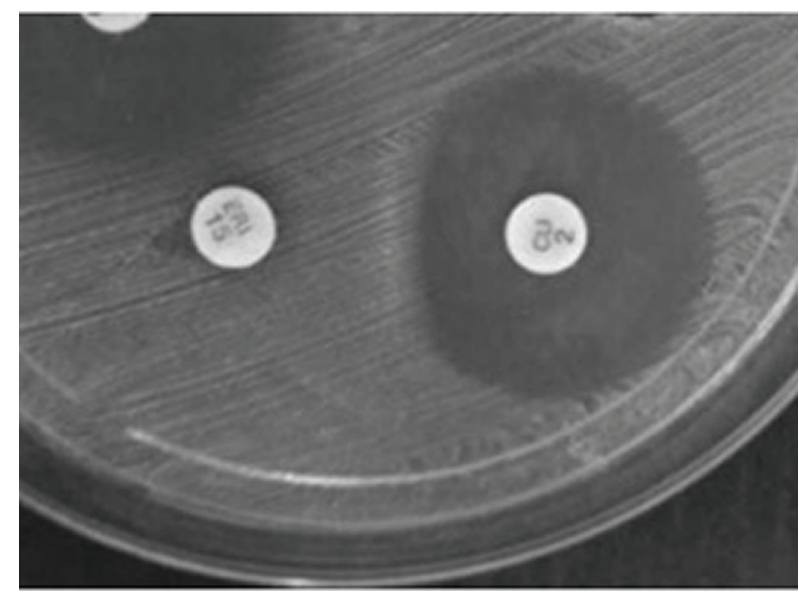

Figure 1 - D-test positive. Halo formed as letter "D" form due to erythromycin-induced resistance.

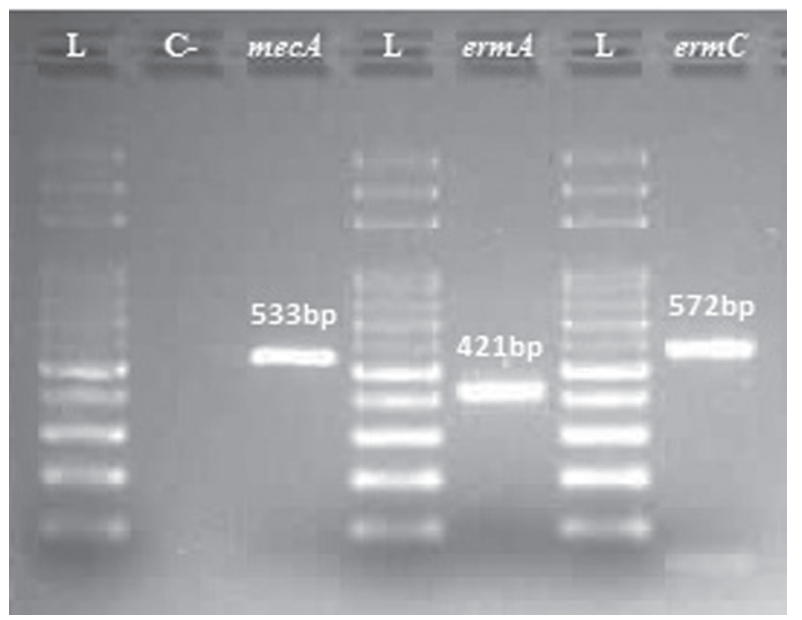

Figure 2 - Electrophoresis gel signifying amplified mecA (533 bp), ermA (421 bp) and erm C (572 bp) genes from the same strain. L: ladder (100 bp). C-: negative control (S.aureus ATCC 29213). 
Results obtained from Kappa estimates for concordance between detection of resistance are summarized at Tables III, IV and V. In relation to the prevalence of $S$. aureus resistance gene carrier strains, there were no difference observed in males and females $(\mathrm{p}<0.05)$.

\section{DISCUSSION}

Resistance to multiple antibiotics frequently observed in Staphylococcus aureus strains due to defense mechanisms against drugs has lead to limiting therapeutic choices and a prolonged treatment period of infections (Lima et al. 2015). In the present study, $20.6 \%$ of samples were positive for S. aureus. This prevalence corroborate to the data of Catão et al. (2012), that reported prevalence of $20.0 \%$ positive samples for $S$. aureus collected from a hospital team of public healthcare employees. Atique et al. (2012) identified 33.3\% samples positive for $S$. aureus isolated from the nasal mucosa of students, while Silva et al. (2012) discussed that colonization can vary from 20 to $30 \%$ in samples isolated from healthcare workers. Results presented by Pereira and Cunha (2009) showed that 30 of 104 positive samples for Staphylococcus collected from nursing students were $S$. aureus. Predominant rates of MRSA strains can vary mainly due to the size and type of healthcare establishment (Pereira and Cunha 2009).

Resistance to oxacillin was observed in $11.9 \%$ of samples positive for $S$. aureus, which differs

TABLE III

Kappa coefficient to concordance between results for resistance of $S$. aureus strains analyzed by PCR and diskdiffusion tests. Percentage of results concordant in significant level (p) to Kappa statistic, Presidente Prudente, 2007.

\begin{tabular}{lcccc}
\hline Comparison (gene $\mathrm{x}$ antibiotic) & Kappa & Concordant results & $\mathrm{p}$ & Concordance \\
\hline$m e c A$ x oxacilin & 0.2364 & $80.95 \%$ & $0.0487^{*}$ & Weak \\
$m e c A$ x cephoxitin & 0.8286 & $95.24 \%$ & $<0.0001^{*}$ & Excellent \\
erm $A$ x erythromycin & -0.0917 & $59.52 \%$ & 0.1400 & No concordance \\
erm $C$ x erythromycin & 0.1651 & $69.05 \%$ & $0.0259 *$ & Weak \\
\hline
\end{tabular}

$* \mathrm{p}<0.05$.

TABLE IV

Kappa coefficient to concordance between results for resistance to erythromycin of $S$. aureus strains by D test, diskdiffusion and PCR. Percentage of results concordant in significant level (p) to Kappa statistic, Presidente Prudente, 2007.

\begin{tabular}{lcccc}
\hline Comparison (D test $\mathrm{x}$ resistance test) & Kappa & Concordant results & $\mathrm{p}$ & Concordance \\
\hline D test x erythromycin & 0.0349 & $30.95 \%$ & 0.1940 & No concordance \\
D test x ermA & -0.0060 & $42.86 \%$ & 0.4791 & No concordance \\
D test $\mathrm{ermC}$ & 0.1617 & $52.38 \%$ & 0.0789 & No concordance \\
\hline
\end{tabular}
$\mathrm{p}<0.05$.

TABLE V

Kappa coefficient to concordance between results for detection of resistance genes by PCR technique. Percentage of results concordant in significant level (p) to Kappa statistic, Presidente Prudente, 2007.

\begin{tabular}{lcccc}
\hline Comparison & Kappa & Concordant resuts & $\mathrm{p}$ & Concordance \\
\hline mecA $\times$ ermA & -0.2000 & $28.57 \%$ & $0.0154^{*}$ & Weak \\
$m e c A \times \mathrm{erm} C$ & 0.1200 & $47.62 \%$ & 0.0975 & No concordance \\
erm $A$ x erm $C$ & -0.5556 & $28.57 \%$ & $0.0002 *$ & Weak \\
\hline
\end{tabular}

$$
* \mathrm{p}<0.05 \text {. }
$$


from those described by Kobayashi et al. (2009), who evaluated antimicrobial resistance in clinical isolates of Staphylococcus aureus in a public hospital in Goiânia. They found that $68.5 \%$ of samples showed a resistance profile to oxacillin, a difference which can be attributed to the fact that the samples from Kobayashi et al. (2009) study were from a hospital where MRSA was endemic, giving a higher rate of MRSA isolation. Faria et al. (2011) isolated $S$. aureus obtained from nasal vestibules of nursing students and showed that $9.8 \%$ of samples were oxacillin resistant, data that corroborate the findings of the present study. Faria et al. (2011) also found $87.5 \%$ of samples resistant to erythromycin, data that corroborate our study, where $95.2 \%$ of samples were observed to have the same resistance. Nogueira et al. (2009), while assessing hospital infection notifications, found $66.6 \%$ of samples resistant to erythromycin, a level that differs from the findings of this study. These results show that elevated levels of $S$. aureus resistance to erythromycin emphasize the importance of research regarding these bacteria and resistance to this antibiotic. Silva et al. (2010) evaluated the prevalence of $S$. aureus colonizing healthcare professionals in a reference hospital in Recife, Brazil, and identified $17.2 \%$ of isolates resistant to cephoxitin, supporting the prevalence observed in this study. Differently, in Pernambuco, Brazil, Silva et al. (2012) reported that 2.4\% of samples isolated from nurses in a hospital environment were resistant to cephoxitin. In the present study, concordance between results found for resistance to cephoxitin by gene amplification and disk-diffusion tests showed an excellent rate (95.24\%), signifying that the amplification by PCR of the mecA gene indicates a correlation between this gene and resistance to cephoxitin. Some studies have already shown the efficacy of cephoxitin to be a marker for detecting resistance to methicillin by the mecA gene (Colli et al. 2009).
The D test can differentiate between Staphylococci that have inducible resistance (erm gene) and those that have resistance mediated by efflux pump ( $m r s A$ gene) (Moosavian et al. 2014). In regard to the induced resistance to $\mathrm{MLS}_{\mathrm{B}}$, 11 samples (26.2\%) showed positive results. Colli et al. (2009) studied $S$. aureus isolated from nasal and lingual mucosa of adult patients, and identified resistance to clindamycin in $22.2 \%$ of strains. Controversially, the prevalence of $47.2 \%$ of samples resistant to clindamycin observed, Catão et al. (2012) demonstrated susceptibility to clindamycin in $100 \%$ of samples isolated from nasal mucosa of healthcare workers. Divergence between prevalence profile might be related to the mechanisms of induced resistance to $\mathrm{MLS}_{\mathrm{B}}$ that is dependent on gene expression (erm) as well as environmental factors that induce the resistance (Ungureanu 2010).

Presence of gene mecA, which encodes the penicillin-binding proteins (PBPs), was shown to be related to the resistance to methicillin (MRSA) and oxacilin. PBPs are important for cell wall synthesis and are targets of beta lactam antibiotics. MRSA strains are able to express the variant of PBP2, called PBP2a, maintaining its physiological function but, with low affinity to betalactams (Askari et al. 2012, Lima et al. 2015). In this study, strains showed resistance to cephoxitin, evidenced by PCR to evaluate presence of the mecA gene, characterizing the MRSA strain. After a similar study to identify samples displaying MRSA profile that infected nasal mucosa in patients in the intensive care unit (ICT), Ropke et al. (2002) found a prevalence of $14 \%$ MRSA strains, corroborated by the present report, in which a prevalence of $16.6 \%$ was observed in the nasal mucosa from medical students. On the other hand, Mimica and Mendes (2007), in a multi-center study identified that the prevalence of MRSA colonization is variable and dependent on the country, with some rates higher than $80 \%$.

The excessive and inappropriate use of clindamycin has increased the number of $S$. 
aureus strains resistant to $\mathrm{MLS}_{\mathrm{B}}$, and the rate can vary according to the extent of treatment in each country (Abbas et al. 2015, Otsuka et al. 2007). In the present study, $64.2 \%$ of samples were found positive for ermA and $64.2 \%$ for ermC. Moosavian et al. (2014) investigated the genotypic profile of $S$. aureus samples in university hospitals of Iran, and found a $41.1 \%$ prevalence of $S$. aureus with ermA and $17.7 \%$ with erm $C$.

Prevalence of resistance genes to macrolides in S. aureus reported by Schmitz et al. (2000) showed that $74.2 \%$ and $8.6 \%$ of samples from 24 European hospitals were positive for ermA and ermC genes, respectively, and $8.6 \%$ of samples presented both genes. This differs from $64.2 \%$ of samples that presented positive results for ermA, and the same percentage for erm $C$, and $28.5 \%$ for both genes in the present study. Teodoro et al. (2012) characterized the resistance to $\mathrm{MLS}_{\mathrm{B}}$ in MRSA strains analyzing the distribution of erm (A, B and C) and $m r s$ (A) genes in samples from different hospitals, which from a total of 39 MRSA strains, $53.8 \%$ presented the ermA gene and $30.8 \%$ ermC. Moreover, $7.7 \%$ of samples were positive for both genes. Present findings corroborate the previous study that $8.3 \%$ of samples were positive for mecA, ermA and erm $C$ genes characterizing a profile of multidrug resistance.

\section{CONCLUSIONS}

Considering the findings, healthcare students, for instance medical students, can be colonized by multidrug resistant $S$. aureus. The monitoring of irrational use of antibiotics by the population is fundamental to prevent the emergence of new multidrug resistant strains. Students and healthcare professionals that attend a nosocomial environment have to be oriented and aware of hygiene protocols, and the use of personal protective equipment (PPE) is essential to prevent and control the dissemination of infectious agents, mainly multidrug resistant strains.

\section{ACKNOWLEDGMENTS}

The authors are grateful for the financial support provided by the Universidade do Oeste Paulista UNOESTE.

\section{REFERENCES}

ABBAS A, SRIVASTAVA P AND NIRWAN PS. 2015. Prevalence of MLSB Resistance and Observation of erm A and erm C Genes At A Tertiary Care Hospital. J Clin Diagn Res 9(6): 8-10.

AMORIM DMR, PERSON OC, AMARAL PJ AND TANAKA II. 2009. Resistência induzível à clindamicina entre isolados clínicos de Staphylococcus aureus. Mundo Saúde 33(4): 401-405.

ASKARI E, SOLEYMANI F, ARIANPOOR A, TABATABAI SM, AMINI A AND NADERINASAB M. 2012. Epidemiology of mecA-Methicillin Resistant Staphylococcus aureus (MRSA) in Iran: A Systematic Review and Metaanalysis. Iran J Microbiol 15(5): 1010-1019.

ATIQUE TSC, LIMA TAM, SOUZA VA, PACHECO PFC AND FURINI AAC. 2012. Sensibilidade à meticilina/ oxacilina de Staphylococcus aureus isolados da mucosa nasal de alunos do Centro Universitário de Rio Preto. Rev Bras Farm 93(3): 347-352.

AYRES M, AYRES JUNIOR M, AYRES DL AND SANTOS AAS. 2007. BioEstat 5.0: Aplicações estatísticas nas áreas das ciências biológicas e médicas. Brasília - DF: Sociedade Civil Mamirauá, 364 p.

CATÃO RMR, BELÉM LF, SILVA PMF, LUIZA FP, NUNES LE AND FERNANDES AFC. 2012. Avaliação da colonização nasal por Staphylococcus aureus em funcionários de um serviço de saúde em Campina Grande - PB. BioFar 7(1): 10-17.

CLSI. 2012. Performance standards for antimicrobial susceptibility testing. CLSI approved standard M100-S15. Clinical and Laboratory Standards Institute, Wayne, PA.

COLLI VC, PIZZOLITTO AC AND RADDI MSG. 2009. Determinação da resistência de Staphylococcus aureus: um desafio? Rev Ciênc Farm Básica Apl 30(1): 115-118.

COUTINHO VLS, PAIVA RM, REITER KC, PARIS F, BARTH AL AND MACHADO ABMP. 2010. Distribution of erm genes and low prevalence of inducible resistance to clindamycin among staphylococci isolates. Braz J Infect Dis 14(6): $564-568$.

DAUREL C, HUET C, DHALLUIN A, BES M, ETIENNE J AND LECLERQ R. 2008. Differences in Potential for Selection of Clindamycin-Resistant Mutants Between Inducible erm(A) and erm(C) Staphylococcus aureus Genes. J Clin Microbiol 46(2): 546-550.

ENRIGTH MC, ROBINSON DA, RANDLE G, FEIL EJ, GRUNDMANN H AND SPRATT BG. 2002. The evo- 
lutionary history of methicillin-resistant Staphylococcus aureus (MRSA). Proc Natl Acad Sci U S A 99(11): 76877692.

FARIA ST, PIEKARSKI AC, TOGNIM MCB, BORELLI SD AND BEDENDO J. 2011. Perfil fenotípico e genotípico de Staphylococcus aureus isolados de estudantes de enfermagem. Acta Paul Enferm 24(2): 213-218.

FINCH R. 2006. Gram-positive infections: lessons learnt and novel solutions. Clin Microbiol Infect 12(8): 3-8.

FITZGERALD JR, STURDEVANT DE, MACKIE SM, GILL SR AND MUSSER JM. 2001. Evolutionary genomics of Staphylococcus aureus: insights into the origin of methicillin-resistant strains and the toxic shock syndrome epidemic. Proc Natl Acad Sci U S A 98(15): 8821-8826.

KOBAYASHI CCBA, SADOYAMA G AND VIEIRA JDG. 2009. Determinação da resistência antimicrobiana associada em isolados clínicos de Staphylococcus aureus e Pseudomonas aeruginosa em um hospital público de Goiânia, Estado de Goiás. Rev Soc Bras Med Trop 42(4): 404-410.

LE LOIR I, BARON F AND GAUTIER M. 2003. Staphylococcus aureus and food poisoning. Genet Mol Res 2(1): 63-76.

LIMA MFP, BORGES MA, PARENTE RS, JÚNIOR RCV AND OLIVEIRA ME. 2015. Staphylococcus aureus e as infecções hospitalares - Revisão de Literatura. Revista UNINGÁ 21(1): 32-39.

MCCULLOCH JA, SILVEIRA ACO, MORAES ACL, PÉREZ-CHAPARRO PJ, SILVA MF, ALMEIDA LM, d'AZEVEDO PAAND MAMIZUKA EM. 2015. Complete Genome Sequence of Staphylococcus aureus FCFHV36, a Methicillin-Resistant Strain Heterogeneously Resistant to Vancomycin. Genome Announc 3(4): e00893-15.

MIMICA MJ AND MENDES CMF. 2007. Diagnóstico laboratorial da resistência à oxacilina em Staphylococcus aureus. J Bras Patol Med Lab 43(6): 399-406.

MOOSAVIAN M, SHOJA S, ROSTAMI S, TORABIPOUR M AND FARSHADZADEH Z. 2014. Inducible clindamycin resistance in clinical isolates of Staphylococcus aureus due to erm genes, Iran. Iran J Microbiol 6(6): 421-427.

MOREIRA ACMG, SANTOS RR AND BEDENDO J. 2013. Prevalência e perfil de sensibilidade de Staphylococcus aureus isolados em pacientes e equipe de enfermagem. Ciênc Cuid Saúde 12(3): 572-579.

MUTO CA, JERNIGAN JA, OSTROWSKY BE, RICHET HM, JARVIS WR, BOYCE JM AND FARR BM. 2003. SHEA guideline for preventing nosocomial transmission of multidrug-resistant strains of Staphylococcus aureus and Enterococcus. Infect Control Hosp Epidemiol 24(5): 362-386.

NIKFAR R, SHAMSIZADEH A, KAJBAF TZ, PANAH MK, KHAGHANI S AND MOGHDDAM M. 2015. Frequency of methicillin-resistant Staphylococcus aureus nasal carriage in healthy children. Iran J Microbiol 7(2): 67-71.
NOGUEIRA PSF, MOURA ERF, COSTA MMF, MONTEIRO WMS AND BRONDI L. 2009. Perfil Da Infecção Hospitalar Em Um Hospital Universitário. Rev Enferm UERJ 17(1): 96-101.

OTSUKA T, ZARAKET H, TAKANO T, SAITO K, DOHMAE S, HIGUCHI W AND YAMAMOTO T. 2007. Macrolidelincosamide-streptogramin B resistance phenotypes and genotypes among Staphylococcus aureus clinical isolates in Japan. Clin Microbiol Infect 13(3): 325-327.

PEREIRA EPL AND CUNHA MLRS. 2009. Avaliação da colonização nasal por Staphylococcus spp. resistente à oxacilina em alunos de enfermagem. J Bras Patol Med Lab 45(5): 361-369.

RATTI RP AND SOUSA CP. 2009. Staphylococcus aureus meticilina resistente (MRSA) e infecções nosocomiais. Rev Ciênc Farm Básica Apl 30(2): 9-16.

RIBEIRO IF, SILVA SFR, SILVA SL, RIBEIRO TR, ROCHA MMNP AND STOLP AMV. 2014. Identificação de Staphylococcus aureus e Staphylococcus aureus resistente à meticilina em estudantes universitários. Rev Ciênc Farm Básica Apl 35(2): 301-304.

ROPKE MRV, BERQUÓ L, SUPERTI S, ROWE F AND DIAS CAG. 2002. Métodos de detecção de Staphylococcus aureus resistente à meticilina (MRSA) como colonizante da mucosa nasal de pacientes internados em unidades de terapia intensiva (UTI). Salão de iniciação Científica, Livro de resumos. Porto Alegre - RS: UFRGS. http://hdl.handle. net/10183/82696.

SADERI H, EMADI B AND OWLIA P. 2011. Phenotypic and genotypic study of macrolide, lincosamide and streptogramin B $\left(\mathrm{MLS}_{\mathrm{B}}\right)$ resistance in clinical isolates of Staphylococcus aureus in Tehran, Iran. Med Sci Monit 17(2): 48-53.

SCHMITZ FJ, SADURSKI R, KRAY A, BOOS M, GEISEL R, KOHRER K, VERHOEF J AND FLUIT AC. 2000. Prevalence of macrolide-resistance genes in Staphylococcus aureus and Enterococcus faecium isolates from 24 European university hospitals. J Antimicrob Chemother 45(6): 891-894.

SILVA ECBF, MACIEL MAV, MELO FL, LOPES ACS AND ACA S. 2010. Epidemiological surveillance and susceptibility of Staphylococcus aureus among healthcare workers at a reference hospital: preliminary assessment. Rev Inst Adolfo Lutz 69(1): 126-130.

SILVA ECBF, SAMICO TM, CARDOSO RR, RABELO MA, NETO AMB, MELO FL AND MACIEL AMV. 2012. Colonização pelo Staphylococcus aureus em profissionais de enfermagem de um hospital escola de Pernambuco. Rev Esc Enferm USP 46(1): 132-137.

TEODOROCRS, MATTOSCS, CAVALCANTEFS, PEREIRA EM AND SANTOS KRN. 2012. Characterization of $\mathrm{MLS}_{\mathrm{b}}$ resistance among Staphylococcus aureus and Staphylococcus epidermidis isolates carrying different SCCmec types. Microbiol Immunol 56(9): 647-650. 
UNGUREANU V. 2010. Macrolides, lincosamides, streptogramines (MLS): mechanisms of action and resistance. Bacteriol Virusol Parazitol Epidemiol 55(2): 131-138.

VIEIRA AJ AND GARRETT JM. 2005. Undestanding interobserver agreement: the kappa statistic. Fam Med 37(5): 360-363.
VIVONI A, DIEP BA, MAGALHÃES ACG, SANTOS KRN, RILEY LW, SENSABAUGH GF AND MOREIRA BM. 2006. Clonal composition of Staphylococcus aureus isolates at a Brazilian university hospital: identification of international circulating lineages. J Clin Microbiol 44(5): 1686-1691. 